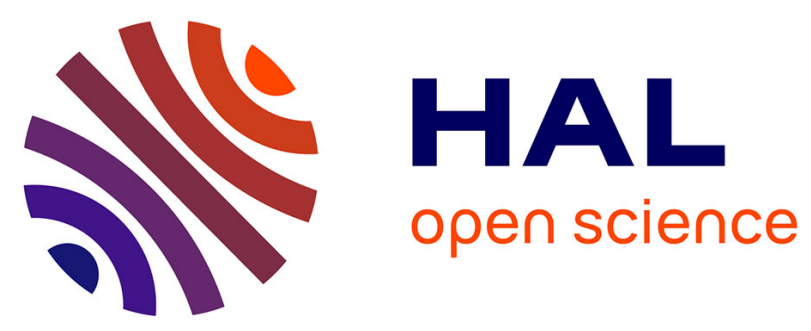

\title{
Formation of metamorphic core complex in inherited wedges: A thermomechanical modelling study
}

Benjamin Huet, Laetitia Le Pourhiet, Loic Labrousse, Evgenii E.B. Burov, Laurent Jolivet

\section{- To cite this version:}

Benjamin Huet, Laetitia Le Pourhiet, Loic Labrousse, Evgenii E.B. Burov, Laurent Jolivet. Formation of metamorphic core complex in inherited wedges: A thermomechanical modelling study. Earth and Planetary Science Letters, 2011, 309 (3-4), pp.249-257. 10.1016/j.epsl.2011.07.004 . insu-00616303

\section{HAL Id: insu-00616303 \\ https://hal-insu.archives-ouvertes.fr/insu-00616303}

Submitted on 10 Oct 2011

HAL is a multi-disciplinary open access archive for the deposit and dissemination of scientific research documents, whether they are published or not. The documents may come from teaching and research institutions in France or abroad, or from public or private research centers.
L'archive ouverte pluridisciplinaire HAL, est destinée au dépôt et à la diffusion de documents scientifiques de niveau recherche, publiés ou non, émanant des établissements d'enseignement et de recherche français ou étrangers, des laboratoires publics ou privés. 


\title{
Formation of metamorphic core complex in inherited wedges: A thermomechanical modelling study
}

\author{
B. Huet ${ }^{\underline{a}, \underline{b}}$, , L. Le Pourhiet $\stackrel{a}{a}, \underline{b}$, L. Labrousse ${ }^{a}, \underline{b}$, E.B. Burov ${ }^{a}, \underline{b}$, L. Jolivet ${ }^{\underline{c}}$ \\ a ISTeP, UMR 7193, T46-00, E2, Case 129, Université Pierre et Marie Curie Paris 06, 4 place \\ Jussieu, 75252, Paris cedex 05, France

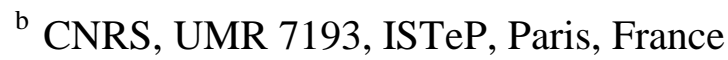 \\ c ISTO, UMR 6113, Université d'Orléans, 1A rue de la Férollerie, 45071 Orléans cedex 02, \\ France
}

\begin{abstract}
Metamorphic Core Complexes (MCCs) form when a thickened domain with a low-strength lower crust is submitted to extension. These structures are characteristic of post-orogenic extension, and field observations suggest that several MCCs rework a crustal nappe-stack emplaced before extension begins. These MCCs therefore develop within heterogeneous crusts that contain pre-existing dipping heterogeneities, such as thrust faults and dipping nappes in a crustal wedge. Although very common, this first order structural inheritance has never been considered in studies modelling MCCs. Our contribution therefore investigates the effect of an inherited crustal wedge structure on the dynamics and kinematics of formation of the MCCs, using fully coupled thermomechanical modelling. The wealth of petrological, structural and time informations available in the Cycladic MCCs (Aegean domain) allows setting up more realistic initial conditions for the experiments than usual flat-lying setups. It also allows the results of the numerical computation to be directly validated with final geometries, $\mathrm{P}-\mathrm{T}$ paths and exhumation rates. The experiments using dipping heterogeneities are characterised by a much more complex evolution and final structure than their flat-lying layered equivalents. Dipping heterogeneities drive lateral strength contrasts and help to relocalise the deformation on successive detachments. The dip of the inherited wedge structures imposes kinematic constraints on the flow, which provides a model that explains the regional scale asymmetry of the Cycladic MCCs. The P-T paths, the exhumation rates and the final crustal structure that come out of an initial shallow-dipping wedge model provide a much more realistic comparison with their natural counter-parts than common flat-lying models. Other parameters, like crustal-scale density inversion, thermal structure and creep law parameters are of second order when compared to the initial wedge structure. Being little dependent on these second order parameters, the proposed model for the formation of MCCs within inherited crustal wedges is likely to be applied to other areas where the MCCs formed in a nappe stack involving continental basement.
\end{abstract}

\section{Introduction}

A metamorphic core complex (MCC) corresponds to a dome of high-grade rocks exhumed from below a lower grade unit through sets of low angle normal faults or detachments (Coney, 1980). These crustal-scale structures develop in the late stages of orogeny in response to extension of thickened crust (Buck, 1991), when the lower crust is weak enough to flow 
laterally toward the dome and compensate the localised thinning of the upper crust (Block and Royden, 1990).

Modelling has provided first order results concerning the formation of the low angle normal faults ( [Brun et al., 1994] , [Gueydan et al., 2004] , [Lavier et al., 1999] and [Tirel et al., 2004a] ) and the influence of lower crustal weakness due to temperature ( [Tirel et al., 2008] and [Wijns et al., 2005] ), partial melting (Rey et al., 2009) and inherited lithological layering (Huet et al., 2011). All of these studies considered models with flat-lying layers and assumed that inherited dipping structures, such as thrusts, are negligible. This assumption does not fully take into account prior crustal thickening typically achieved by nappe stacking. It also ignores the observation that many detachments are former thrusts and that MCC formation overprints crustal-scale wedge structures (Cyclades-Aegean domain (Jolivet et al., 2010), Corsica-Tyrrhenian sea (Daniel et al., 1996), d'Entrecasteaux Islands, Papua New Guinea (Little et al., 2007)).

In this paper, we model the formation of MCCs in inherited crustal-scale wedges. The setup is designed and the experiments are validated by a natural data-set from the Cyclades in the Aegean Sea. We show that the existence of an inherited wedge structure introduces dipping rheological heterogeneities that radically change the dynamics of MCC growth as compared to commonly proposed models with a flat-lying initial geometry. The dip angle of the wedge, the density contrast between the units and the initial thermal gradient are, however, second order parameters.

\section{Design of the numerical experiments}

The numerical experiments have been run with the code FLAMAR v12 (Burov and Cloethingh, 2009). This code solves simultaneously in a Lagrangian formulation for conservation of momentum and heat. The rock behaviour is approximated by visco-elastoplastic rheologies.

The geometry of the crustal-scale wedge is deduced from the inferred structure of the Cyclades before the formation of the MCCs (Fig. 1A). Despite the major reworking of the nappe stack induced by extension, three nappes can be distinguished (Fig. 1B) (Jacobshagen et al., 1978). The lower nappe (the Cycladic Basement) consists of continental basement and corresponds to the northern margin of Apulia, a continental block subducted during the Eocene. The middle nappe (the Attic-Cycladic Blueschist unit) consists of metamorphosed marine sediments and mafic rocks; it corresponds to the Pindos basin, a partly oceanic domain also subducted in the Eocene. The upper nappe (the Pelagonian unit) is a Cretaceous ophiolite complex and represents the uppermost unit in the largest part of the Aegean Sea. At the onset of extension, this nappe stack constituted a crustal-scale wedge (Figs. 1A and 2A). As the initial slope of the wedge is an unknown parameter, we vary it from $15^{\circ}$ to $45^{\circ}$ and compare the results with a regular flat-lying model.

The upper nappe is mostly composed of mafic and ultramafic rocks. It is therefore considered to be the most competent layer of the crust. The middle nappe, which consists of slivers of schists and marbles with scattered inclusions of mafic material, is considered the weakest. The lower basement nappe, mainly represented by granites and gneissic rocks, is given an intermediate behaviour. This reversed rheological layering is consistent with numerous field observations of strain localisation at the Cyclades scale: the strain gradient between the upper and the middle nappes on Tinos (Mehl et al., 2005) and Andros (Mehl et al., 2007), and the strain being localised in the lower nappe while 
pervasive in the middle nappe on Ios ( [Huet et al., 2009] and [Vandenberg and Lister, 1996] ). The viscous rheology of the lower, middle and upper nappes are therefore respectively modelled by intermediate, soft and strong creep laws available for those lithologies (Huet et al., 2011). The parameters are listed in Table 1 and the corresponding yield strength envelopes are represented on Fig. 2B. The overall rheological structure is therefore characterised by a weak dipping heterogeneity in the middle crust that was previously referred to a "dipping-pie" (Le Pourhiet et al., 2004) and is known to introduce lateral variation of the crustal strength profile (Fig. 2A) .

The upper nappe is mostly composed of mafic and ultramafic rocks. It is therefore considered to be the most competent layer of the crust. The middle nappe, which consists of slivers of schists and marbles with scattered inclusions of mafic material, is considered the weakest. The lower basement nappe, mainly represented by granites and gneissic rocks, is given an intermediate behaviour. This reversed rheological layering is consistent with numerous field observations of strain localisation at the Cyclades scale: the strain gradient between the upper and the middle nappes on Tinos (Mehl et al., 2005) and Andros (Mehl et al., 2007), and the strain being localised in the lower nappe while pervasive in the middle nappe on Ios ( [Huet et al., 2009] and [Vandenberg and Lister, 1996] ). The viscous rheology of the lower, middle and upper nappes are therefore respectively modelled by intermediate, soft and strong creep laws available for those lithologies (Huet et al., 2011). The parameters are listed in Table 1 and the corresponding yield strength envelopes are represented on Fig. 2B. The overall rheological structure is therefore characterised by a weak dipping heterogeneity in the middle crust that was previously referred to a "dipping-pie" (Le Pourhiet et al., 2004) and is known to introduce lateral variation of the crustal strength profile (Fig. 2A) .

\section{Dynamics and kinematics of the metamorphic core complex formation within a crustal-scale wedge}

In all the experiments, the stretching results in the formation of MCCs. These MCCs share a lot of common dynamic and kinematic patterns introduced by the reactivation of the crustal wedge structure. However, in these models, the preexisting thrust faults are not introduced explicitly as discrete frictional planes. The term of reactivation therefore does not describe frictional processes along the pre-existing thrusts but a kinematic constraint related to the rheological structure. In this part, the evolution with time of the case with a $25^{\circ}$ dip is given in detail because this captures most of the kinematic complexity introduced by the presence of a wedge. The impact of the wedge dip on the model results is then discussed in the context of the other experiments.

In the first kyrs, extension is accommodated by right-dipping normal faults located where the upper crust is the thinnest and rooting in the middle crust (f1a, f1b, f1c and f1d on Fig. 3A). At greater depth, the same stretching is accommodated by a right-dipping normal shear zone that roots in the middle/lower nappe contact (sz1 on Fig. 3A). Such kinematics is indeed dynamically imposed by the dip of the wedge (Le Pourhiet et al., 2004). Necking of the upper nappe occurs after $c a$. $2 \mathrm{Myr}$, when the fault f1d, lying above the flat-ramp transition of the wedge, reaches the middle/lower nappe contact (Fig. 3B).

From that point on, three successive right-dipping detachments exhume the lower nappes within two domes (Fig. 3G). The first detachment (d1 on Fig. 3B) exhumes a proto-dome mainly consisting of the lower nappe (D1). This dome is laterally fed by a viscous channel (vc 
on Fig. 3B). The top of the channel roots in the contact between the upper and middle nappes and switches up below the brittle-ductile transition (BDT) of the upper nappe at $5 \mathrm{Myr}$ (Fig. 3C). This first detachment resumes its activity after exhuming a large recumbent fold of lower nappe. The hinge of this fold is truncated between 10 and $16 \mathrm{Myr}$ by a right-dipping fault rooting into the second detachment (d2 on Fig. 3D) and a left-dipping conjugate normal fault (f2). These first and second detachments exhume the first large dome cored and rimmed by the middle nappe (D1 on Fig. 3E). Meanwhile, a small dome of lower nappe develops below the core of D1, where the lower nappe is initially at its thinnest. This is exhumed to mid-crustal level by left-dipping conjugate normal shear-zones cross-cutting the contact between the middle and lower nappes. After $16 \mathrm{Myr}$, the second detachment is abandoned and active deformation switches toward the right, onto the third detachment (d3 on Fig. 3E-F). This shallower detachment roots in the upper/middle nappe contact. In association with its conjugate left-dipping normal fault (f3 on Fig. 3E-F), it exhumes a second dome exposing the middle nappe at the surface, lying above a thin layer of upper nappe at depth (D2).

Even though the detachments have their conjugate normal counterparts in the upper levels of the model, the top-to-the-right kinematics is dominant in the lower levels. The localisation and kinematics of the detachments are also controlled by the dipping heterogeneities: the middle-lower nappe contact for the first detachment (Fig. 3B-C), the overturned middle-lower nappe contact for the second detachment (Fig. 3D) and the upper-middle nappe contact for the third detachment (Fig. 3E-F). As a result, the dipping heterogeneities inherited from the initial wedge structure introduce large localised lateral velocity gradients, which localise the deformation and serve as localisation factor that impose the asymmetry of the exhumed MCCs. Migration of the deformation from one detachment to another is controlled by the strength of the exhumed material (Huet et al., 2011). Such dynamics is consistent with the dipping-pie dynamics studied at smaller scale in the case of the Corinth rift (Le Pourhiet et al., 2004). During the activity of the second and the third detachments (10-20 Myr), a lowmagnitude extension occurs in the left-hand side of the model along high-angle normal faults. This results in reduced thinning and boudinage of the upper nappe.

The sequential evolution of the experiments with $15^{\circ}, 35^{\circ}$ and $45^{\circ}$ dips are presented in Figures SM1, SM2 and SM3 of the supplementary material, respectively. Fig. 4A-D shows that the dip angle of the thrust in the initial crustal-scale wedge has no major influence on the dynamics of MCC formation, expressed as the final geometries and the $\mathrm{P}-\mathrm{T}$ paths. The differences are due to the relative amount of middle and lower nappe in the wedge. The less lower nappe is present (i.e. the higher the thrust dip is), the less the first dome is developed and the sooner the transition to the second dome occurs. Moreover, the synthetic $\mathrm{P}-\mathrm{T}$ paths show that exhumation of deep material is enhanced when the dip of the thrust is low (Fig. 4A-D). The size of the dome of lower nappe below the core of the first dome increases with the dip angle. This progressive evolution shows that the localisation mechanism in dipping heterogeneities is less efficient for high thrust dip angles, although it is dominant.

\section{Comparison with common flat-lying models}

Fig. 4E presents the final geometry of a model with flat-lying crustal layers (hereafter referred as "flat model"). The sequential evolution is presented in Figure SM4 of the supplementary material. The initial and boundary conditions of the flat model are the same as for the models with an initial wedge geometry (hereafter referred as "wedge models"). The details of the dynamics of the flat model have been presented in (Huet et al., 2011). Here we concentrate on five aspects in which the wedge models strongly differ from the flat-lying model: necking of 
the upper crust, development of the crustal asymmetry, structural complexity, $\mathrm{P}-\mathrm{T}$ paths shapes and exhumation rates.

The first step of MCC development is controlled by necking of the upper crust which corresponds to extreme thinning achieved by normal faults (Tirel et al., 2004a). In the wedge models, necking of the upper crust appears above the uppermost bend of the middle nappe, whereas it is controlled by the boudinage wavelength of the upper crust in the flat model (Huet et al., 2011). The wedge structure has therefore a major influence on the initiation of MCCs.

In the flat models, three factors are likely to produce asymmetry in the MCCs: rapid strainsoftening within the detachment ( [Huismans et al., 2005] and [Lavier et al., 1999] ), a prescribed normal fault in the upper crust (Rey et al., 2009), or the ability of the lower crust to flow toward the dome in one sense only ( [Huet et al., 2011] and [Tirel et al., 2006] ). In the wedge models, asymmetry is inherited from the prescribed geometry of the middle crust according to "dipping-pie" dynamics (Le Pourhiet et al., 2004). The flat and ramp geometry of the middle nappe has the same effect as the prescribed normal fault, even if they are not located at the same depth in the crust.

Successive detachments develop by successive rooting in one another in the flat model whereas detachments properly switch from one nappe contact to another nappe contact in the wedge models. Due to these jumps, the lower plate of the detachments changes in the wedge models. Especially, part of the middle nappe belongs to the upper plate of the first detachment (Fig. 3B-C), whereas it is finally exhumed by the third detachment (Fig. 3E-F), meaning that deformation can migrate upward, which is not observed in the flat model. Moreover, the isolation of the lower nappe fold hinge locally produces a crustal overturn between the middle and the lower nappe. Such an overturned fold, generally considered as being restricted to compressive settings, could be produced by stretching of an initially complex structure. As a result, the realistic initial geometry induces a complex final structure even with continuous and simple boundary conditions (Fig. 4).

In the wedge models, the detachments and the current BDT switch locations with time and produce important changes of the viscous channel geometry and activity. The experiments show that, under these conditions, the thickness of the viscous channel remains approximately constant with time (Fig. 3). This contrasts with the flat model, in which the channel thins as the dome grows (Huet et al., 2011). This structural evolution is recorded in the maximum exhumation rates (Fig. 5A), which remain constant or slowly decrease with time in the wedge models instead of decreasing dramatically with time in the flat model. However, the mean exhumation rates of the flat model are larger than those of the wedge models (Fig. 5B), which can be explained by the occurrence of exhumation pulses at the onset of extension in the case of the flat model. The larger spatial distribution and the steady lower crustal flow in the wedge models results in a slightly more distributed thinning of the crust and therefore a flatter Moho (Fig. 4).

The differences in exhumation dynamics is recorded by the P-T paths in two ways (Fig. 4). First, the maximum pressure of the exhumed lower nappe is higher in the wedge models $(1.2$ $\mathrm{GPa})$ than in the flat model $(0.9 \mathrm{GPa})$. This feature is due to the second detachment of the wedge models that exhumes deeper lower nappe material while cross-cutting the overturned fold. Second, the wedge models exhibit a characteristic heating of $100{ }^{\circ} \mathrm{C}$ at broadly constant pressure within the second domes. These $\mathrm{P}-\mathrm{T}$ paths reflect the heating of the upper plate 
during the exhumation of the first dome before the detachment switches higher in the nappe stack.

\section{Comparison with the Cycladic MCCs}

Here we compare the wedge models with the Cycladic MCCs that were used to design their setups. The Cycladic nappe stack was built within a north-dipping subduction zone induced by the convergence between the Apulian and Eurasian plates (Jolivet et al., 2004b) (Fig. 1A). The related thrusts exhibit top-to-the-south displacements ( [Huet et al., 2009] , [Lacassin et al., 2007] , [Ring et al., 2007a] and [Ring et al., 2007b] ). N-S extension within the nappestack was triggered by the retreat of the subduction zone to the south at $\mathrm{ca} 30 \mathrm{Ma}$ (Jolivet and Faccenna, 2000). We therefore consider the final stage of the models as a synthetic N-S cross section of the Cyclades with the north at the right side of the models. The experiments apply to the time period between $30 \mathrm{Ma}$ which corresponds to onset of back-arc retreat (Jolivet and Faccenna, 2000) and $10 \mathrm{Ma}$ which is the average low-temperature age in the lower units (Ring et al., 2010).

The spatial distribution of domes and units predicted by the numerical experiments reproduces well those found in the Cyclades (Fig. 1B). The lower nappe is located in the central and the southern part of the exhumed domain (equivalent to the Cycladic basement of Naxos and Ios) whereas the middle nappe is dominant in the northern part of the exhumed domain (equivalent to the Attic-Cycladic Blueschist unit of Tinos). The reactivation of a Ndipping rheological heterogeneity inherited from the formation of the wedge provides a mechanically feasible explanations for the dominant top-to-the-north sense of shear recorded at a regional scale (Jolivet et al., 2004a). Moreover, as the wedge deforms, the rheological in homogeneities change shape and provide mechanisms for deformation to localise higher in the nappe-stack as extension proceeds, as observed at smaller scales in the Northern Cyclades (Jolivet et al., 2010).

This migration with time of the localised deformation in the wedge models results in a flatter Moho than in regular flat-lying models. In the case with a $15^{\circ}$ dip, the modelled Moho lies broadly flat at a depth of $22 \mathrm{~km}$, which compares well with the gravimetric inversion that infers a flat Moho at $\sim 25 \mathrm{~km}$ depth below the Cyclades (Tirel et al., 2004b). The discrepancy of $3 \mathrm{~km}$ between the mechanical model and the gravimetric model, if significant, could result from differences in the total thinning between the model and reality.

Synthetic P-T paths extracted from the models can be compared to their natural counterparts. The islands of Naxos and Tinos have been chosen because they represent two thermal and structural end-members of the Cycladic MCCs (Jolivet et al., 2004a) but also because they are the only MCCs for which the whole $\mathrm{P}-\mathrm{T}-\mathrm{t}$ evolution during the MCC formation is constrained (Martin, 2004 and [Parra et al., 2002] ). The distribution and the shape of the natural $\mathrm{P}-\mathrm{T}$ paths are best reproduced by the models where the wedge is initially shallow dipping $\left(15^{\circ}\right.$ and $25^{\circ}$, Fig. $\left.4 \mathrm{~A}-\mathrm{B}\right)$. Both deep lower nappe and intermediate middle nappe are exhumed in the left-hand side dome (equivalent to Naxos), and middle nappe, with heating at constant pressure, is exhumed in the right-hand side dome (equivalent to Tinos). Note that even if isobaric heating in the model occurs at $0.2 \mathrm{GPa}$ below the pressure recorded in the $\mathrm{P}-$ $\mathrm{T}$ path of Tinos (Parra et al., 2002), such a P-T path has never been recovered in MCC models with an initial flat layering ( [Huet et al., 2011] , [Rey et al., 2009] and [Tirel et al., 2009] ) (Fig. 4E). The fit between natural and synthetic P-T paths does not match as well as 
in the case of models with initial high-angle wedges $\left(35^{\circ}\right.$ and $\left.45^{\circ}\right)$ since the deepest parts of the crust are not exhumed in these cases (Fig. 4C-D).

The mean exhumation rates computed for the shallow dip wedge models $\left(15^{\circ}\right.$ and $\left.25^{\circ}\right)$ are in accordance with those computed from the P-T-t paths of Naxos ( [Duchêne et al., 2006] and Martin, 2004) and Tinos (Parra et al., 2002) (Fig. 5B). As in the natural record, the exhumation rates of the lower nappe are larger than those of the middle nappe. The values are matched for the middle nappe of Naxos and Tinos and the synthetic values are less than 1 mm. $\mathrm{yr}^{-1}$ greater than the natural ones for the lower nappe of Naxos. This latter discrepancy, together with the absence in the models of $100{ }^{\circ} \mathrm{C}$ heating during exhumation of the lower nappe (Fig. 4A-B), are likely to reflect the intrusions and partial melting that accompanied the exhumation of Naxos (Vanderhaeghe, 2004), processes that were not included in our models.

Magmatic intrusions have been proposed to impact the dynamics of the MCCs ( [Lister and Baldwin, 1993] , [Rey et al., 2009] and [Tirel et al., 2004a] ). Widespread synkinematic intrusions were emplaced in the Cyclades between 22 and $8 \mathrm{Ma}$ (see Pe-Piper and Piper (2002) and references therein). However, most of them belong to the late stages of the formation of the Cycladic MCCs, after $15 \mathrm{Ma}$. In Mykonos, it is clearly demonstrated by both thermological (Brichau et al., 2008) and structural (Denèle et al., 2011) studies that the intrusion did not trigger extension and rather behaved as a passive body which inprinted the kinematics of the previously existing North Cycladic Detachment System (Jolivet et al., 2010). We therefore consider that the intrusions have no impact on the initial stages of the Cycladic MCCs. Their mechanical impact, if it exists, is limited to the latter stages of exhumation.

\section{Discussion}

In the experiments presented so far, we have neglected the density contrast between the units of the nappe stack, the initial thermal structure related to the formation of the wedge and made some approximation on the creep parameters. Here we discuss the model sensitivity to these different approximations and the applicability of the wedge models to other MCCs.

The initial structure of the crustal wedge in the Aegean, with an ophiolitic upper nappe lying over felsic lower nappes, suggests that a crustal-scale density inversion existed prior to extension. The inversion of the density structure due to stacking is limited by the sensibility of rock density to pressure so that a low-grade basic unit may have almost the same density as a felsic unit metamorphosed in the blueschist facies (Bousquet et al., 1997). However, the three wedge models run with density values of 2800,2900 and $3000 \mathrm{~kg} \cdot \mathrm{m}^{-3}$ for the upper unit and of $2700 \mathrm{~kg} \cdot \mathrm{m}^{-3}$ for the lower units (Fig. 6B-C-D and Figures SM5, SM6 and SM7 of the supplementary material) share the major characteristics with those that do not take into account any density contrast (Fig. 6A). For large density contrasts, small scale RayleighTaylor instabilities develop within in the viscous channel (Fig. 6C-D), leading to an increased mixing of the upper and the lower unit in the viscous channel, but do not modify the main kinematics and dynamics of MCC formation in wedge models.

Crustal-scale nappe stacking laterally perturbs the thermal structure of the wedge while building it (Thomson and Ridley, 1987). In turn, this thermal perturbation induces rheological heterogeneities that are superposed on those induced by the geometry. Evaluating in detail the thermal effects of stacking on the development of MCCs in a crustal wedge would require a 
parametric study, which is beyond the scope of this paper. Underthrusting of cool units below a warmer upper plate would strengthen the lower crust and therefore prevent the formation of MCCs (Buck, 1991). At the contrary, when the lower units of MCCs are former blueschist- or eclogite-facies crustal slices, their history involves burying, partial exhumation and then stacking during continental collision (Jolivet et al., 2003). In these cases, the lower units warm up the bottom of the crustal wedge (Burov et al., 2001). This thermal perturbation lowers the viscous strength of the lower units of the wedge and hence promotes the dynamics and kinematics described in Section 3. Besides, it must be kept in mind that MCCs develop in regions where the crust has reached or is reaching thermal equilibrium after stacking (Gaudemer et al., 1988). Finally, experiments run with a cooler (Fig. 6E) or a warmer (Fig. 6F) Moho temperature (sequential evolution presented in Figures SM8 and SM9 of the supplementary material) are roughly similar to the one run with $810^{\circ} \mathrm{C}$ at the Moho (Fig. $6 \mathrm{E}$ ).

The models presented so far invoke an inversion of the rheological layering, with strong rocks in the upper crust, i.e. quartz-diorite (Hansen and Carter, 1982), and soft rocks in the lower crust, i.e. dry quartz (Ranalli and Murphy, 1987) and dry granite (Hansen and Carter, 1982). On the one hand, using softer creep laws for the lower units or stronger ones for the upper unit would lead to a sharper strength contrast between the upper unit and the lower units. That rheological layering would increase the "dipping-heterogeneity effect" and hence would promote the dynamical and kinematic control of the initial wedge structure and the formation of MCCs. On the other hand, using a "classical" rheological layering would change the mode of extension. The exhumation of strong lower crust would lead to continuous migration of the deformation and the development of a wide rift instead of MCCs (Huet et al., 2011).

Furthermore, the continental crust is sometimes considered to be weaker than the strength as deduced from experiments on dry rocks (Bürgmann and Dresen, 2008). We therefore ran an experiment with weak rheologies for the three units while keeping the relative strength contrasts (upper crust: dry granite ephansen1982, middle crust: wet quartz (Ranalli, 1995), lower crust: dry quartz (Ranalli and Murphy, 1987)). This rheological structure led to the exhumation of lower crust along conjugate detachments (Figure SM10 of the supplementary material), which marks a reduced "dipping-heterogeneity effect".

The wedge model can be applied to other MCCs formed after a continental collision. Alpine Corsica (Tyrrhenian Sea) and d'Entrecasteaux islands (Papua-New Guinea) are two examples of described MCCs which present similarities with the initial conditions of our wedge model set-up. In Corsica, the European margin has been underthrusted to the east, below the oceanic Schiste-Lustrés unit (Mattauer et al., 1981). In the d'Entrecasteaux islands, the north of the Australian passive margin has been underthrusted to the north, below the Papuan ultramafic body (Davies and Jacques, 1984). In both cases, the MCCs reworked a crustal scale nappe stack and exhumed basement material along detachments that have the same dip and opposite kinematics as the thrusts, i.e. east-dipping detachment in Corsica (Daniel et al., 1996) and north-dipping in Papua New Guinea (Little et al., 2007).

\section{Conclusion}

Numerical experiments provide new insights on the formation of MCCs in crusts with an inherited wedge structure. Although we use simple (but realistic) boundary conditions and initial geometries, the predicted MCC show a very complex evolution and final structure when compared to models with flat-lying layers. Structures such as overturned folds, which would be a posteriori considered to be related to the thrusting phase of deformation, can actually form during post-collisional extension. The dynamics of exhumation is mainly 
controlled by the dipping heterogeneities which generate lateral strength contrasts and localise the successive detachments. Besides, the overall kinematics in the brittle and ductile domains is imposed by the dip of the inherited wedge structure throughout the formation of the MCC. The wedge models with shallow dipping thrusts recover the $\mathrm{P}-\mathrm{T}$ paths shape and zonation, the exhumation rates and the crustal structure of the Cycladic MCCs of the Aegean domain. They also provide an explanation for the dominant kinematics in the Cyclades, namely the reactivation of inherited thrusts as detachments. The dip angle of the wedge, the density contrast between the units and the initial thermal gradient being second order parameters, we posit that the model of MCC formation in an inherited wedge applies to MCCs which clearly formed in a nappe stack involving continental basement lying below an upper strong ophiolitic unit.

\section{Acknowledgements}

This paper is a contribution to the ANR-EGEO project. Scientific comments and English polishing from Jason Saleeby and Hugh Rice improved the quality of the manuscript. We also thank T. Gerya and an anonymous reviewer for their valuable remarks which helped to improve the first version of this article, as well as T.M. Harrisson for editorial handling.

\section{References}

Block and Royden, 1990 L. Block and L. Royden, Core complex geometries and regional scale flow in the lower crust. Tectonics, 9 (1990), pp. 557-567.

Bousquet et al., 1997 R. Bousquet, B. Goffé, P. Henry, X. Le Pichon and C. Chopin, Kinematic, thermal and petrological model of the central alps: Lepontine metamorphism in the upper crust and eclogitisation of the lower crust. Tectonophysics, 273 105-127 (1997).

Brichau et al., 2008 S. Brichau, U. Ring, A. Carter, R. Bolhar, P. Monié, D. Stöckli and M. Brunel, Timing, slip rate, displacement and cooling history of the Mykonos detachment footwall, Cyclades, Greece, and implications for the opening of the Aegean sea basin. J. Geol. Soc., 165 (2008), pp. 263-277.

Brun et al., 1994 J.P. Brun, D. Sokoutis and J. Van Den Driessche, Analogue modeling of detachment fault systems and core complexes. Geology, 22 (1994), pp. 319-322.

Buck, 1991 W.R. Buck, Modes of continental lithospheric extension. J. Geophys. Res., 96 B12 (1991), pp. 20161-20178.

Bürgmann and Dresen, 2008 R. Bürgmann and G. Dresen, Rheology of the lower crust and upper mantle: evidence from rock mechanics, geodesy, and field observations. Annu. Rev. Earth Planet. Sci., 36 (2008), pp. 531-567

Burov and Cloethingh, 2009 E.B. Burov and S.A.P.L. Cloethingh, Controls of mantle plumes and lithospheric folding on modes of intraplate continental tectonics: differences and similarities. Geophys. J. Int., 178 (2009), pp. 1691-1722.

Burov et al., 2001 E. Burov, L. Jolivet, L. Le Pourhiet and A. Poliakov, A thermomechanical model of exhumation of high pressure (hp) and ultra-high pressure (uhp) metamorphic rocks in alpine-type collision belts. Tectonophysics, 342 113-136 (2001). 
Chopra and Paterson, 1984 P. Chopra and M.S. Paterson, The role of water in the deformation of dunite. J. Geophys. Res., 89 (1984), pp. 7861-7876

Coney, 1980 P.J. Coney, Cordilleran metamorphic core complexes: an overview. Geol. Soc. Am. Mem., 153 (1980), pp. 7-31.

Daniel et al., 1996 J.-M. Daniel, L. Jolivet, B. Goffé and C. Poinssot, Crustal-scale strain partitioning: footwall deformation below the Alpine Oligo-Miocene detachment of Corsica. $J$. Struct. Geol., 181 (1996), pp. 41-59.

Davies and Jacques, 1984 H.L. Davies and A.L. Jacques, Emplacement of ophiolite in Papua New Guinea. Geol. Soc. Lond. Spec. Publ., 13 (1984), pp. 341-350.

Denèle et al., 2011 Y. Denèle, E. Lecomte, L. Jolivet, O. Lacombe, L. Labrousse, B. Huet and L. Le Pourhiet, Granite intrusion in a metamorphic core complex: the example of the Mykonos laccolith (Cyclades, Greece). Tectonophysics, 501 (2011), pp. 52-70.

Duchêne et al., 2006 S. Duchêne, R. Aïssa and O. Vanderhaeghe, Pressure-temperature-time evolution of metamorphic rocks from Naxos (Cyclades, Greece): Constraints from thermobarometry and Rb/Sr dating. Geodin. Acta, 195 (2006), pp. 301-321.

Gaudemer et al., 1988 Y. Gaudemer, C. Jaupart and P. Tapponnier, Thermal control on postorogenic extension in collision belts. Earth Planet. Sci. Lett., 89 48-62 (1988).

Gueydan et al., 2004 F. Gueydan, Y. Leroy and L. Jolivet, Mechanics of low-angle extensional shear zones at the brittle-ductile transition. J. Geophys. Res., 109 B12 (2004).

Hansen and Carter, 1982 F.D. Hansen and N.L. Carter, Creep of selected crustal rocks at 1000 mpa (1982).

Huet et al., 2009 B. Huet, L. Labrousse and L. Jolivet, Thrust or detachment? Exhumation processes in the Aegean: insight from a field study on Ios (Cyclades, Greece).

Tectonics, 28 (2009).

Huet et al., 2011 B. Huet, L. Le Pourhiet, L. Labrousse, E. Burov and L. Jolivet, Postorogenic extension and metamorphic core complexes in a heterogeneous crust; the role of crustal layering inherited from collision. application to the Cyclades (Aegean domain). Geophys. J. Int., (2011).

Huismans et al., 2005 R. Huismans, S.J.H. Buiter and C. Beaumont, The effect of plasticviscous layering and strain-softening on mode selection during lithospheric extension. $J$. Geophys. Res., 110 (2005).

Jacobshagen et al., 1978 V. Jacobshagen, S. Dürr, F. Kockel, K.O. Kopp, G. Kowalczyk, H. Berckhemer and D. Büttner, Structure and geodynamic evolution of the Aegean region, H. Cloos, D. Roeder, K. Schmidt, Editors, Alps, Apennines, Hellenides. Vol. report 38, IUGG, Stuttgart (1978), pp. 537-564.

Jolivet and Brun, 2010 L. Jolivet and J.P. Brun, Cenozoic geodynamic evolution of the Aegean. Int. J. Earth Sci., 991 (2010). 
Jolivet and Faccenna, 2000 L. Jolivet and C. Faccenna, Mediterranean extension and the Africa-Eurasia collision. Tectonics, 196 (2000), pp. 1095-1106

Jolivet et al., 2003 L. Jolivet, C. Faccenna, B. Goffé, E. Burov and P. Agard, Subduction tectonics and exhumation of high-pressure metamorphic rocks in the Mediterranean orogens. Am. J. Sci., 303 (2003), pp. 353-409.

Jolivet et al., 2004a L. Jolivet, V. Famin, C. Mehl, T. Parra, C. Aubourg, R. Hebert and P. Philippot, Strain localization during crustal-scale boudinage to form extensional metamorphic domes in the aegean sea.; gneiss domes in orogeny, . Spec. Pap. Geol. Soc. Am., 380 (2004), pp. 185-210 serial.

Jolivet et al., 2004b L. Jolivet, G. Rimmelé, R. Oberhänsli, B. Goffé and O. Candan, Correlation of syn-orogenic tectonic and metamorphic events in the Cyclades, the Lycian Nappes and the Menderes massif, geodynamic implications. Bull. Geol. Soc. Fr., 1753 (2004), pp. 217-238.

Jolivet et al., 2010 L. Jolivet, E. Lecomte, B. Huet, Y. Denèle, O. Lacombe, L. Labrousse, L. Le Pourhiet and C. Mehl, The north cycladic detachment system. Earth Planet. Sci. Lett., 289 1-2 (2010), pp. 87-104.

Lacassin et al., 2007 R. Lacassin, N. Arnaud, P.H. Leloup, R. Armijo and B. Meyer, Syn- and post-orogenic exhumation of metamorphic rocks in north Aegean, . eEarth, 22 (2007), pp. 51-63 eE 1815-381X.

Lavier et al., 1999 L.L. Lavier, W. Roger Buck and A.N.B. Poliakov, Self-consistent rollinghinge model for the evolution of large-offset low-angle normal faults. Geology, 2712 (1999), pp. 1127-1130.

Le Pourhiet et al., 2004 L. Le Pourhiet, E. Burov and I. Moretti, Rifting through a stack of inhomogeneous thrusts (the dipping pie concept). Tectonics, 23 TC4005 (2004).

Lister and Baldwin, 1993 G. Lister and S.L.A. Baldwin, Plutonism and the origin of metamorphic core complexes. Geology, 21 607-610 (1993).

Little et al., 2007 T.A. Little, S.L. Baldwin, P.G. Fitzgerald and B. Monteleone, Continental rifting and metamorphic core complex formation ahead of the Woodlark Spreading Ridge, D'entrecasteaux Islands, Papua New Guinea. Tectonics, 26 (2007).

Martin, 2004 Martin, L., 2004. Signification des âges u-pb sur zircon dans l'histoire métamorphique de naxos et Ikaria (Cyclades, Grèce). Thèse de doctorat, Université Henri Poincaré..

Mattauer et al., 1981 M. Mattauer, M. Faure and J. Malavieille, Transverse lineation and large scale structures related to Alpine obduction in Corsica. J. Struct. Geol., 3 (1981), pp. 401409.

Mehl et al., 2005 C. Mehl, L. Jolivet and O. Lacombe, From ductile to brittle; evolution and localization of deformation below a crustal detachment (Tinos, Cyclades, Greece).

Tectonics, 24 (2005). 
Mehl et al., 2007 C. Mehl, L. Jolivet, O. Lacombe, L. Labrousse and G. Rimmelé, Structural evolution of Andros (Cyclades, Greece); a key to the behaviour of a (flat) detachment within an extending continental crust.; the geodynamics of the Aegean and Anatolia, . Geol. Soc. Spec. Publ., 291 (2007), pp. 41-73 serial.

Parra et al., 2002 T. Parra, O. Vidal and L. Jolivet, Relation between deformation and retrogression in blueschist metapelites of Tinos Island (Greece) evidenced by chlorite-mica local equilibria. Lithos, 63 (2002), pp. 41-66.

Pe-Piper and Piper, 2002 G. Pe-Piper and D. Piper, The igneous rocks of Greece. The anatomy of an orogen, Beiträge zur Regionalen Geologie der Erde (2002).

Ranalli, 1995 G. Ranalli, Rheology of the Earth, Chapman and Hall, London (1995).

Ranalli and Murphy, 1987 G. Ranalli and D.C. Murphy, Rheological stratification of the lithosphere. Tectonophysics, 132 (1987), pp. 281-295.

Rey et al., 2009 P.F. Rey, C. Teyssier and D.L. Whitney, Extension rates, crustal melting, and core complex dynamics. Geology, 375 (2009), pp. 391-394.

Ring et al., 2007a U. Ring, J. Glodny, T. Will and S. Thomson, An oligocene extrusion wedge of blueschist-facies nappes on Evia, Aegean Sea, Greece; implications for the early exhumation of high-pressure rocks, . J. Geol. Soc. Lond., 1643 (2007), pp. 637-652 serial. |

Ring et al., 2007b U. Ring, T. Will, J. Glodny, C. Kumerics, K. Gessner, S. Thomson, T. Gungor, P. Moie, M. Okrusch and K. Drueppel, Early exhumation of high pressure rocks in extrusion wedges; cycladic blueschist unit in the eastern Aegean, Greece, and Turkey. Tectonics, 26 (2007).

Ring et al., 2010 U. Ring, J. Glodny, T. Will and S. Thomson, The hellenic subduction system: high-pressure metamorphism, exhumation, normal faulting, and large-scale extension. Annu. Rev. Earth Planet. Sci., 38 (2010), pp. 45-76

Thomson and Ridley, 1987 A.B. Thomson and J.R. Ridley, Pressure-temperature-time (p-tt) histories of orogenic belts. Philos. Trans. R. Soc. Lond., $32127-45$ (1987).

Tirel et al., 2004a C. Tirel, J.-P. Brun and E. Burov, Thermomechanical modeling of extensional gneiss domes. Geol. Soc. Am. Spec. Pap., 380 (2004), pp. 67-78.

Tirel et al., 2004b C. Tirel, F. Gueydan, C. Tiberi and J.-P. Brun, Aegean crustal thickness inferred from gravity inversion. geodynamical implications. Earth Planet. Sci. Lett., 228 3-4 (2004), pp. 267-280.

Tirel et al., 2006 C. Tirel, J.P. Brun and D. Sokoutis, Extension of thickened and hot lithospheres: inferences from laboratory modeling. Tectonics, 251 (2006).

Tirel et al., 2008 C. Tirel, J.-P. Brun and E. Burov, Dynamics and structural development of metamorphic core complexes. J. Geophys. Res., 113 B04403 (2008). 
Tirel et al., 2009 C. Tirel, P. Gautier, D.J.J. van Hinsbergen and M.J.R. Wortel, Sequential development of interfering metamorphic core complexes: numerical experiments and comparison with the Cyclades, Greece. Geol. Soc. Lond. Spec. Publ., 3111 (2009), pp. 257292.

Vandenberg and Lister, 1996 L.C. Vandenberg and G.S. Lister, Structural analysis of basement tectonics from the Aegean metamorphic core complex of Ios, Cyclades, Greece. $J$. Struct. Geol., 1812 (1996), pp. 1437-1454.

Vanderhaeghe, 2004 O. Vanderhaeghe, Structural record of the Naxos dome formation, D.L. Whitney, C. Teyssier, C.S. Siddoway, Editors, Gneiss Dome in Orogeny. Vol. 380 of Special Paper, Geological Society of America, Boulder, CO (2004), pp. 211-227

Wijns et al., 2005 C. Wijns, R. Weinberg, K. Gessner and L. Moresi, Mode of crustal extension determined by rheological layering. Earth Planet. Sci. Lett., 236 1-2 (2005), pp. 120-134. 


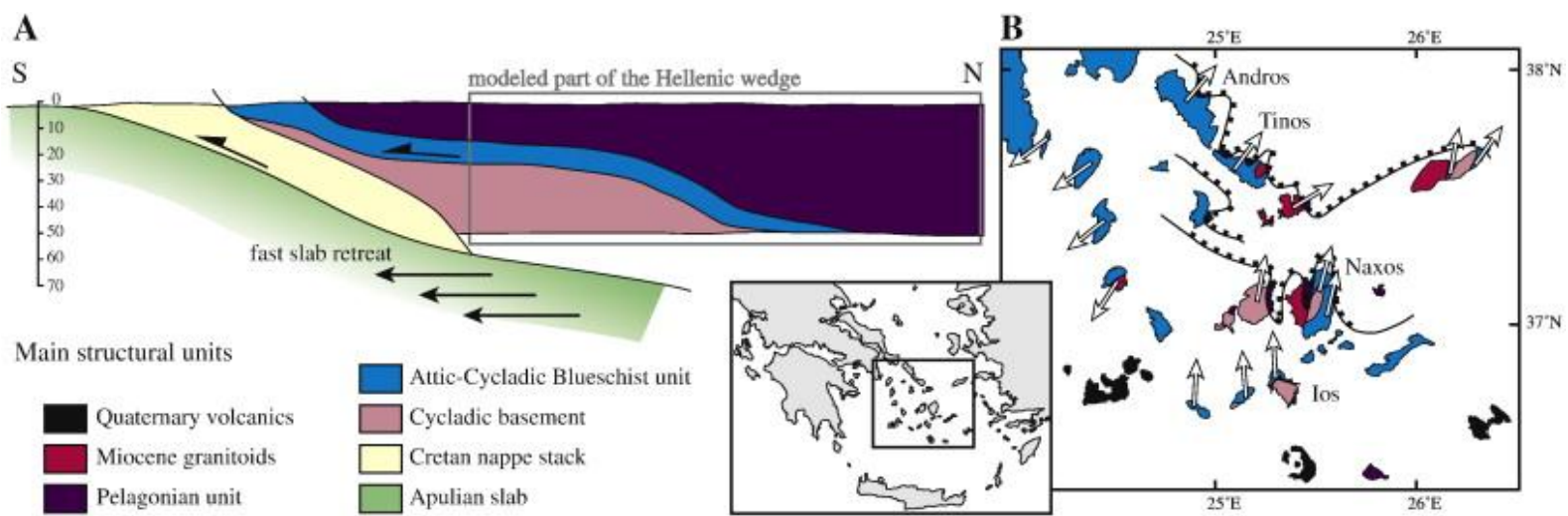

Fig. 1. : Geological context. A: Schematic cross-section of the Hellenic subduction zone at the onset of extension. Modified after Jolivet and Brun (2010). B: Structural map of the Cyclades (Huet et al., 2009). The MCCs are associated with north-dipping detachments and to top-tothe-north or north-east deformation in the lower plate (Attic-Cycladic Blueschist unit and Cycladic basement). The Pelagonian unit constitutes the upper plate of the MCCs. The white arrows indicate the sense of ductile shear in the lower plate.

A

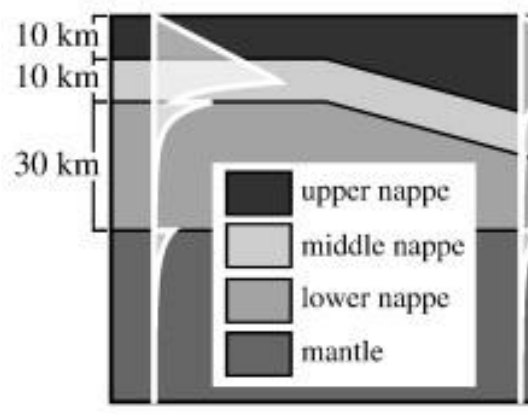

C

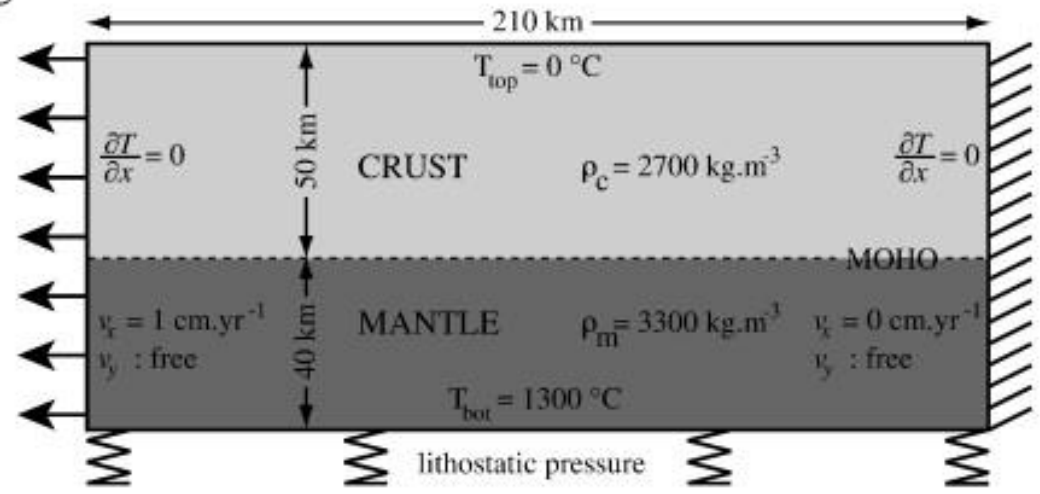

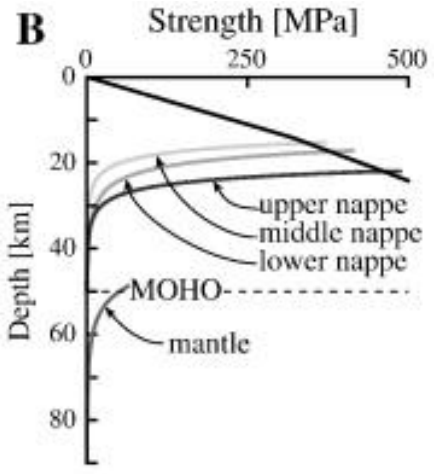

D Temperature $\left[{ }^{\circ} \mathrm{C}\right]$

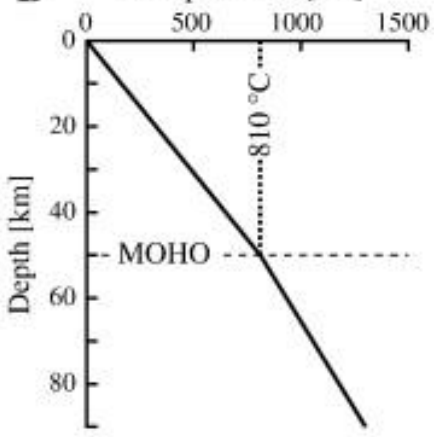

Fig. 2. :Design of the experiments. (A) Geometry of the models and inital strength profiles. (B) Initial strength profiles of the nappes and the mantle. (C) Initial and boundary conditions. (D) Initial temperature profile. 
Table 1. Value of density and creep parameters $(A, n, Q)$ used in the experiments presented in $\underline{3}$ and $\underline{4}$.

\begin{tabular}{|c|c|c|c|c|c|c|}
\hline & \multirow[t]{2}{*}{ Material } & $\begin{array}{l}\text { Density at } 25 \\
{ }^{\circ} \mathrm{C}\end{array}$ & $A$ & $\mathbf{n}$ & $Q$ & \multirow[t]{2}{*}{ Ref. } \\
\hline & & $\left(\mathrm{kg} \cdot \mathrm{m}^{-3}\right)$ & $\left(\mathrm{MPa}^{-\mathrm{n}} \cdot \mathrm{s}^{-}\right.$ & & $\left(\mathbf{k J} \cdot \mathrm{mol}^{-}\right.$ & \\
\hline $\begin{array}{l}\text { Upper } \\
\text { nappe }\end{array}$ & $\begin{array}{l}\text { Quartz- } \\
\text { diorite }\end{array}$ & 2700 & $1.3 .10^{-3}$ & 2.4 & 219 & $\begin{array}{l}\text { Hansen and Carter } \\
\underline{(1982)}\end{array}$ \\
\hline $\begin{array}{l}\text { Middle } \\
\text { nappe }\end{array}$ & Dry quartz & 2700 & $6.7 .10^{-6}$ & 2.4 & 156 & $\frac{\text { Ranalli and Murphy }}{(1987)}$ \\
\hline $\begin{array}{l}\text { Lower } \\
\text { nappe }\end{array}$ & Dry granite & 2700 & $2.0 .10^{-6}$ & 3.3 & 186 & $\underline{\text { Hansen and Carter }}$ \\
\hline Mantle & Dry dunite & 3300 & $2.5 .10^{-4}$ & 3.5 & 532 & $\begin{array}{l}\text { Chopra and Paterson } \\
(1984)\end{array}$ \\
\hline
\end{tabular}




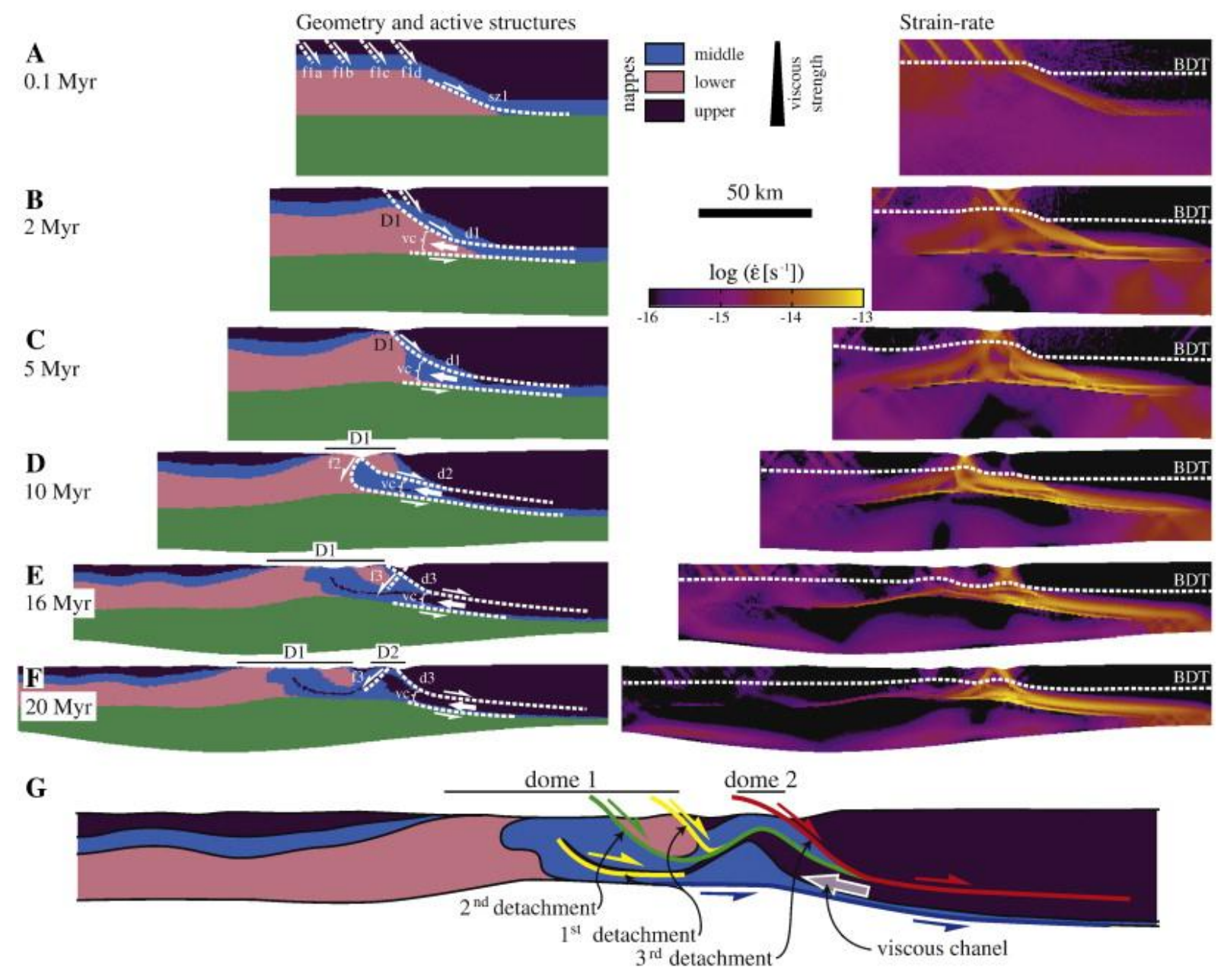

Fig. 3. : (A-F) Sequential evolution of the exhumation of a MCC in a crustal scale wedge (the thrust dips at $25^{\circ}$ ). Left panel: geometry and active structures. Right panel: strain-rate and brittle-ductile transition (BDT). (G) Main features of the model showing the two domes exhumed by the three successive detachments and fed by a lower crustal viscous channel. 

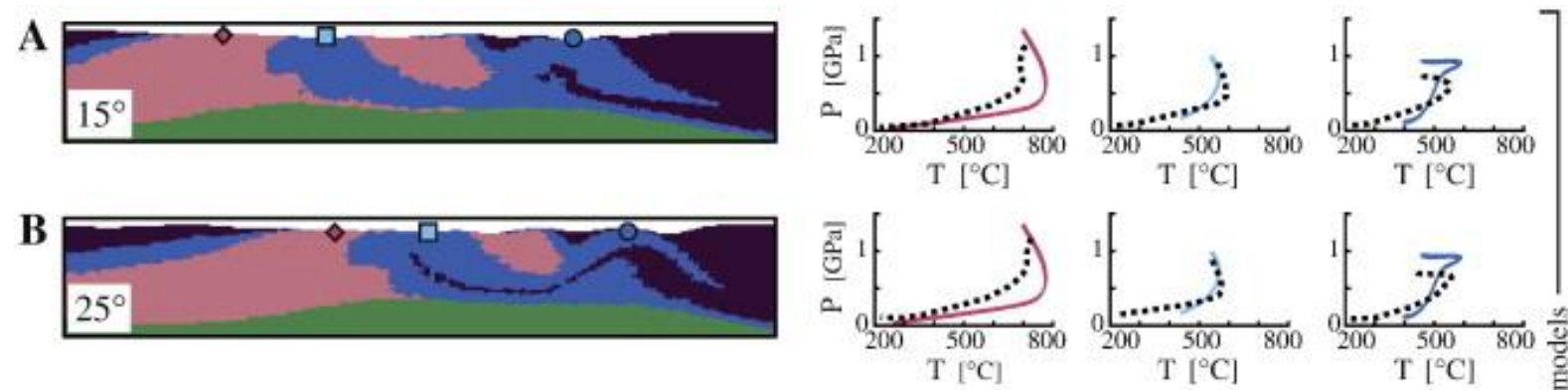

$\mathrm{C}$
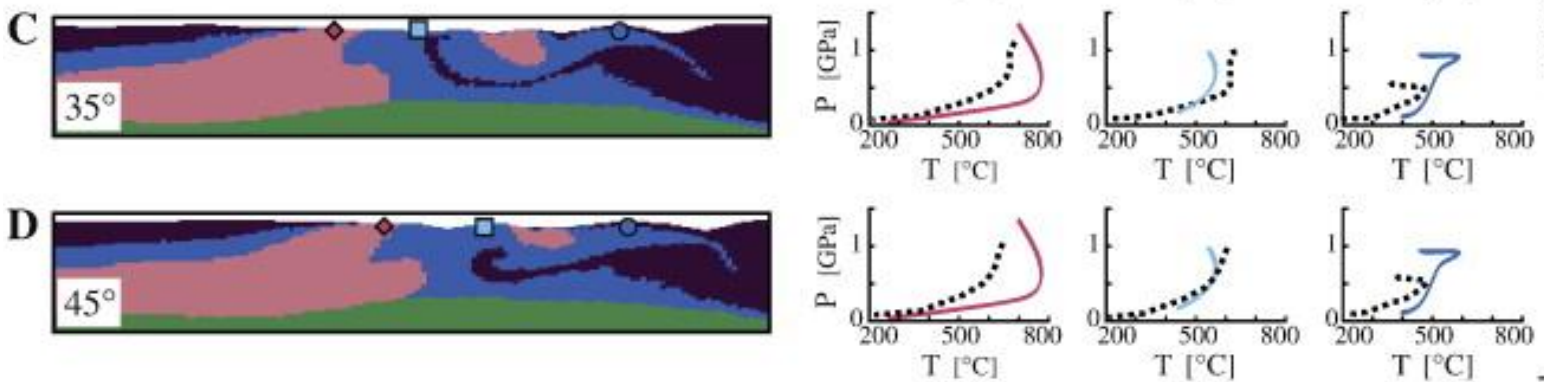

E
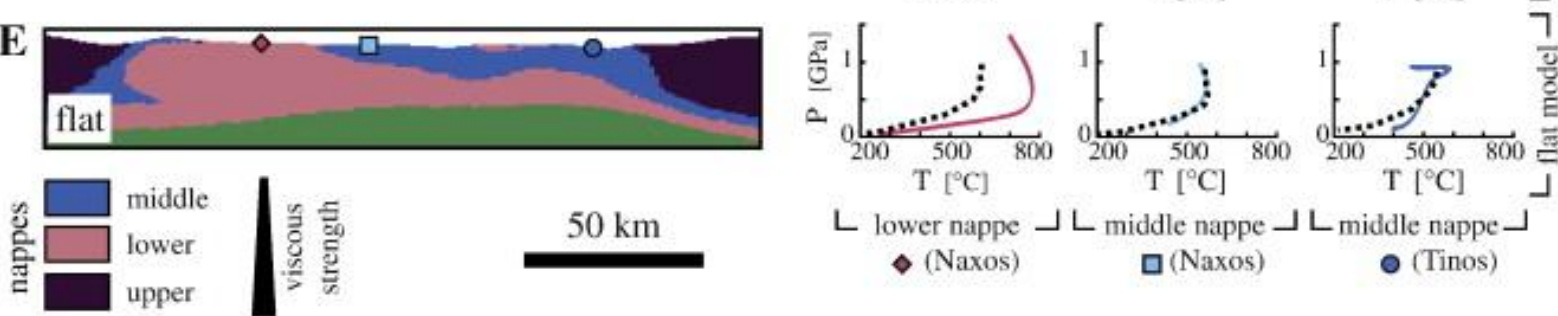

$50 \mathrm{~km}$

ᄂ lower nappe $\bullet$ (Naxos)

$\square$ (Naxos)

- (Tinos)

Fig. 4.

Final geometry and $\mathrm{P}-\mathrm{T}$ paths for wedge type models with initial thrusts dipping at $15^{\circ}(\mathrm{A})$, $25^{\circ}(\mathrm{B}), 35^{\circ}(\mathrm{C})$ and $45^{\circ}$ (D). A model with flat-lying crustal layers (E) which has been run with the same initial and boundary conditions is also presented (Huet et al., 2011). Black dotted lines correspond to the synthetic $\mathrm{P}-\mathrm{T}$ paths and colour lines correspond to their natural counterparts (Martin, 2004 and [Parra et al., 2002] ). The sequential evolution of the experiments with initial thrusts dipping $15^{\circ}, 35^{\circ}(\mathrm{C})$ and $45^{\circ}$ is presented in Figures SM1, SM2 and SM3 of the supplementary material, respectively. The sequential evolution of the flat model is presented in Figure SM4 of the supplementary material. 

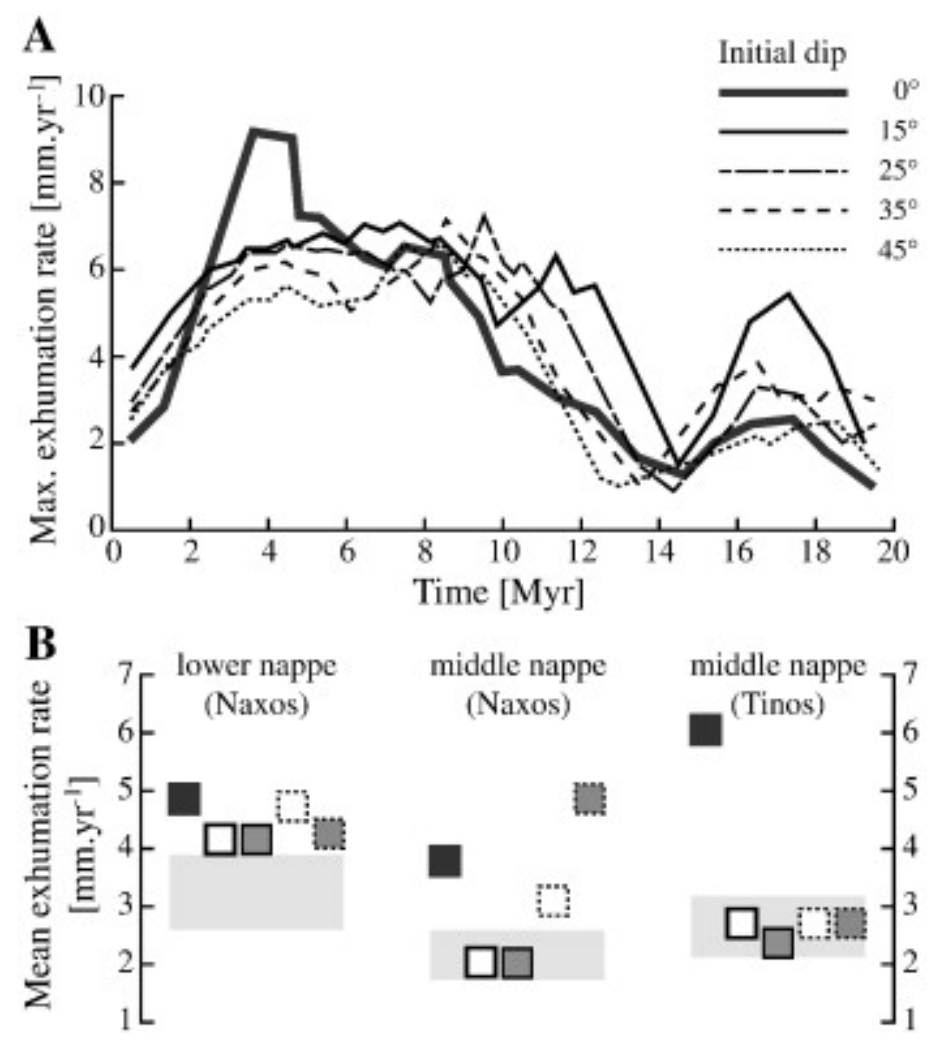

Computed values, initial dip

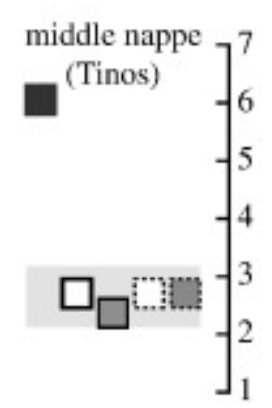

Mesured values

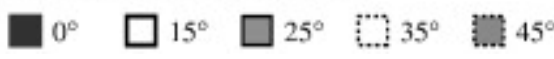

Fig. 5. : (A) Envelope of the maximum exhumation rates for the four wedge models and the flat model. The gap at $c a$. $15 \mathrm{Myr}$ exhibited by the curves of the wedge models correspond to the transition between the first and the second dome. (B) Comparison between the mean exhumation rates of the models for the markers displayed on Fig. 4 and those computed from the P-T-t paths of Tinos (Parra et al., 2002) and Naxos ( [Duchêne et al., 2006] and Martin, 2004). A constant error of $20 \%$ has been assigned to the natural exhumation rates. 


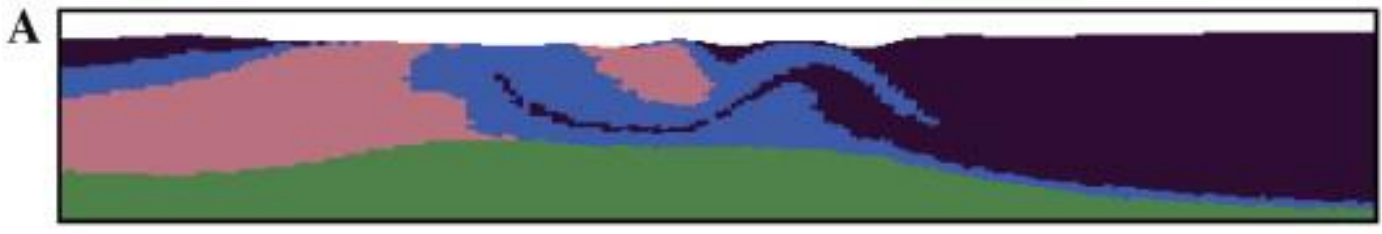

B

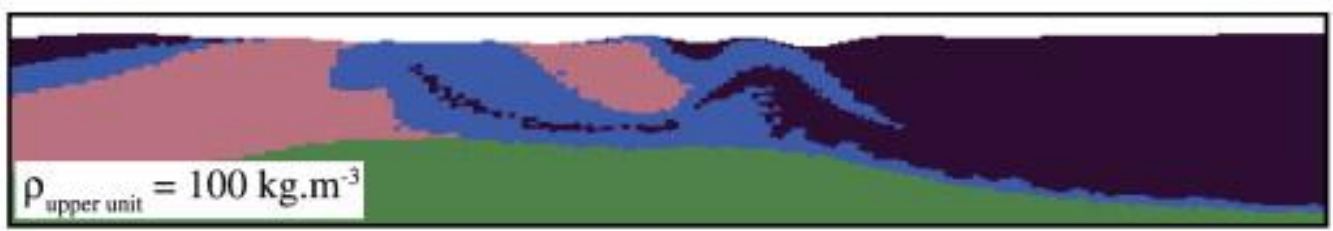

C

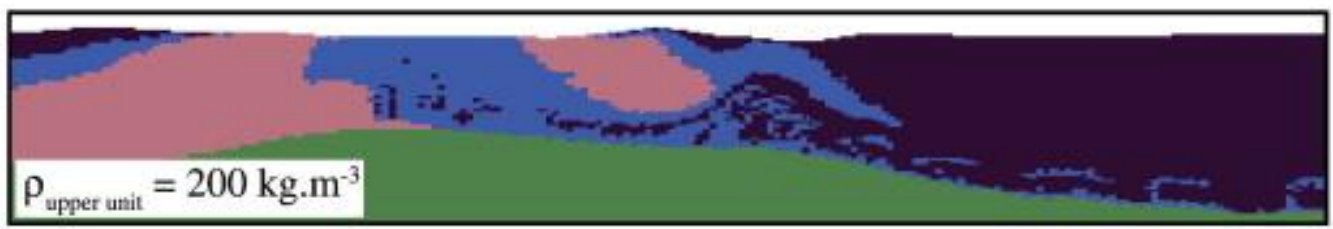

D

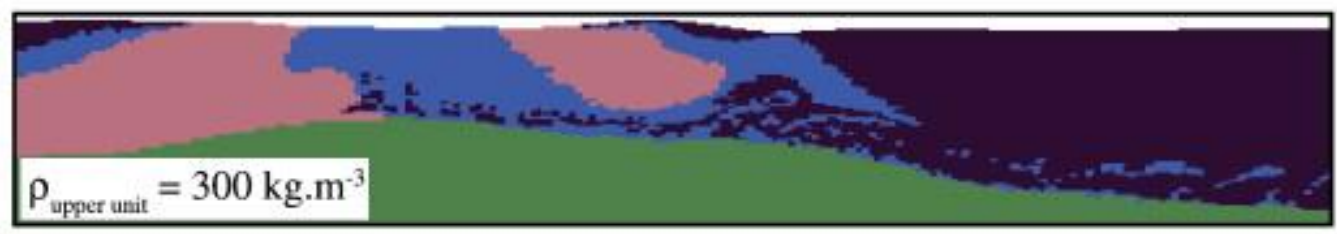

E

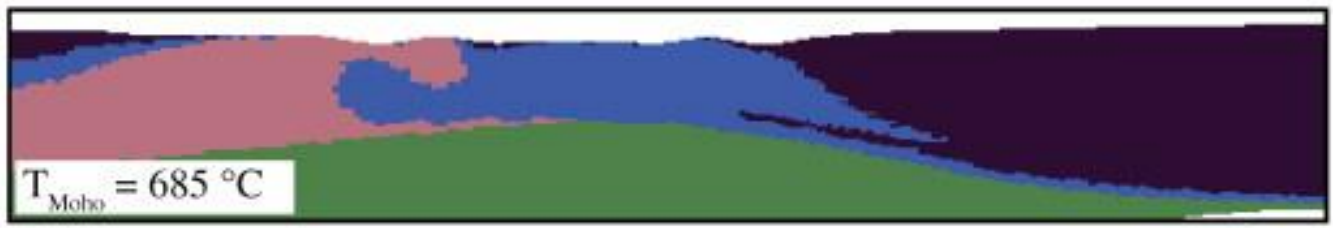

F

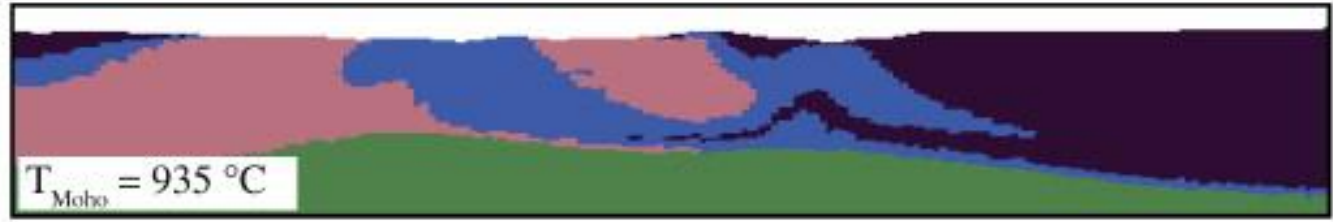

G

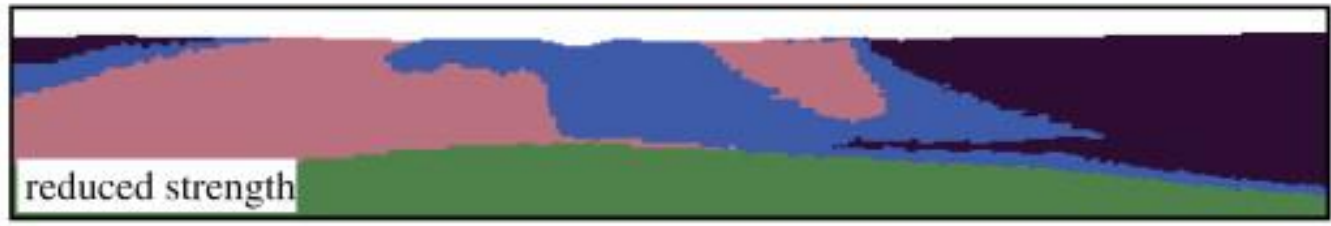

nappes

middle

lower

upper

$50 \mathrm{~km}$

viscous strength

Fig. 6. : Final geometry for wedge models with initial thrusts dipping at $25^{\circ}$. The reference experiment (A) is presented in Section 3 and in Fig. 3. As compared to this reference experiment, the varied parameters are: density of the upper unit (B: $2800 \mathrm{~kg} \cdot \mathrm{m}^{-3}, \mathrm{C}: 2900$ kg.m ${ }^{-3}$, D: $3000 \mathrm{~kg} \cdot \mathrm{m}^{-3}$ ), initial Moho temperature (E: $\left.685^{\circ} \mathrm{C}, \mathrm{F}: 935{ }^{\circ} \mathrm{C}\right)$ and creep laws $(\mathrm{G}$ : upper unit-dry granite, middle unit-wet quartz, lower unit-dry quartz). The creep parameters of dry granite and dry quartz are listed in Table 1. The creep parameters of wet quartz are: $n=$ 2.3, $A=3.2 .10^{-4} \mathrm{MPa}^{-n} \cdot \mathrm{s}^{-1}$ and $Q=154 \mathrm{~kJ} \cdot \mathrm{mol}^{-1}$ (Ranalli, 1995). The sequential evolution of the last 6 experiments is presented in Figures SM5, SM6, SM7, SM8, SM9 and SM10 of the supplementary material, respectively. 
